\title{
Comparison of the Current Diagnostic Criterion of HbA1c with Fasting and 2-Hour Plasma Glucose Concentration
}

\author{
Rudruidee Karnchanasorn, ${ }^{1}$ Jean Huang, ${ }^{2,3}$ Horng-Yih Ou, ${ }^{4}$ Wei Feng, ${ }^{2,3}$ \\ Lee-Ming Chuang, ${ }^{5,6}$ Ken C. Chiu, ${ }^{2,3}$ and Raynald Samoa ${ }^{2,3}$ \\ ${ }^{1}$ Division of Endocrinology, Department of Medicine, University of Kansas Medical Center, Kansas City, KS 66160, USA \\ ${ }^{2}$ Department of Clinical Diabetes, Endocrinology, and Metabolism, City of Hope National Medical Center, Duarte, \\ CA 91010, USA \\ ${ }^{3}$ Division of Endocrinology, Metabolism and Nutrition, Department of Internal Medicine, Harbor-UCLA Medical Center, \\ Torrance, CA 90502, USA \\ ${ }^{4}$ Division of Endocrinology and Metabolism, Department of Internal Medicine, National Cheng Kung University Hospital, \\ College of Medicine, National Cheng Kung University, Tainan, Taiwan \\ ${ }^{5}$ Department of Internal Medicine, National Taiwan University Hospital, Taipei, Taiwan \\ ${ }^{6}$ Graduate Institute of Preventive Medicine, School of Public Health, National Taiwan University, Taipei, Taiwan
}

Correspondence should be addressed to Ken C. Chiu; kenchiumd@gmail.com

Received 20 April 2016; Revised 17 July 2016; Accepted 19 July 2016

Academic Editor: Sergiu Catrina

Copyright (C) 2016 Rudruidee Karnchanasorn et al. This is an open access article distributed under the Creative Commons Attribution License, which permits unrestricted use, distribution, and reproduction in any medium, provided the original work is properly cited.

\begin{abstract}
To determine the effectiveness of hemoglobin Alc (HbAlc) $\geq 6.5 \%$ in diagnosing diabetes compared to fasting plasma glucose (FPG) $\geq 126 \mathrm{mg} / \mathrm{dL}$ and 2-hour plasma glucose $(2 \mathrm{hPG}) \geq 200 \mathrm{mg} / \mathrm{dL}$ in a previously undiagnosed diabetic cohort, we included 5,764 adult subjects without established diabetes for whom HbAlc, FPG, 2hPG, and BMI measurements were collected. Compared to the FPG criterion, the sensitivity of $\mathrm{HbAlc} \geq 6.5 \%$ was only $43.3 \%$ (106 subjects). Compared to the $2 \mathrm{hPG}$ criterion, the sensitivity of HbAlc $\geq 6.5 \%$ was only $28.1 \%$ (110 subjects). Patients who were diabetic using $2 \mathrm{hPG}$ criterion but had $\mathrm{HbAlc}<6.5 \%$ were more likely to be older ( $64 \pm 15$ versus $60 \pm 15$ years old, $P=0.01$, mean \pm STD), female ( $53.2 \%$ versus $38.2 \%, P=0.008)$, leaner ( $29.7 \pm 6.1$ versus $\left.33.0 \pm 6.6 \mathrm{~kg} / \mathrm{m}^{2}, P=0.000005\right)$, and less likely to be current smokers (18.1\% versus $\left.29.1 \%, P=0.02\right)$ as compared to those with $\mathrm{HbAlc} \geq 6.5 \%$. The diagnostic agreement in the clinical setting revealed the current $\mathrm{HbAlc} \geq 6.5 \%$ is less likely to detect diabetes than those defined by FPG and 2hPG. HbAlc $\geq 6.5 \%$ detects less than $50 \%$ of diabetic patients defined by FPG and less than $30 \%$ of diabetic patients defined by $2 \mathrm{hPG}$. When the diagnosis of diabetes is in doubt by HbAlc, FPG and/or $2 \mathrm{hPG}$ should be obtained.
\end{abstract}

\section{Introduction}

Diabetes has reached epidemic proportions in the US and worldwide [1]. The estimated total economic cost of diagnosed diabetes in 2012 was $\$ 245$ billion in the US alone [2]. Diabetes and its complications are serious and potentially life-threatening, but the disease process can be halted or slowed by effective treatment [3]. In 2014, according to the Center for Disease Control and Prevention, 25.8 million people in the United States have diabetes and 1.9 million people aged 20 years or older were newly diagnosed in 2010 alone based on either fasting plasma glucose (FPG) or hemoglobin Alc (HbAlc) criterion [4]. Seven million people with diabetes are undiagnosed, and a large percentage of newly diagnosed individuals already have complications at the time of diagnosis. Because most patients with early diabetes are asymptomatic, effective screening tests are crucial, and early identification of diabetes and initiation of appropriate treatment are vital to patients' health. Evidence suggests that early diagnosis and proper treatment of type 2 diabetes confer health benefits, whereas aggressive control of blood glucose, blood pressure, and cholesterol after diagnosis of type 2 diabetes may be less important than early screening [5]. Additionally, delaying screening and treatment 
for type 2 diabetes may hasten and/or increase the risk for developing cardiovascular diseases. Thus, reliable screening and diagnostic methods are necessary to identify individuals at risk. To achieve this goal, a simplified diagnostic test has been proposed by the measurement of HbAlc by various organizations.

HbAlc is produced by a nonenzymatic reaction that occurs between glucose and hemoglobin, which was first characterized in 1968 [6]. Elevated HbAlc in diabetic patients was first reported by Rahbar et al. in 1969 [7]. As plasma glucose increases, the fraction of HbAlc increases in a predictable way. This serves as a surrogate marker for average blood glucose levels over the previous months prior to the measurement. Subsequently, the clinical application of $\mathrm{HbAlc}$ in monitoring glycemic control in diabetic patients was demonstrated in 1976 [8]. Since then, the measurement of HbAlc has become a standard in the care of patients with diabetes and for monitoring glycemic control over a 3month period. Aggressive improvement in glycemic control, as demonstrated by a reduction in $\mathrm{HbAlc}$, reduced the rate of diabetic complications and improved quality of life [9]. However, due to lack of standardization of the HbAlc assay, it was not until 2009 that HbAlc was incorporated as a diagnostic tool for diabetes [10]. This was mainly achieved through the effort of the National Glycohemoglobin Standardization Program (NGSP) [11]. In 2010, the American Diabetes Association included $\mathrm{HbAlc} \geq 6.5 \%(48 \mathrm{mmol} / \mathrm{mol})$ as a diagnostic criterion based on its correlation with retinopathy [10]. Since then, only one longitudinal study has validated the inflection point of $\mathrm{HbAlc} \geq 6.5 \%(48 \mathrm{mmol} / \mathrm{mol})$ for increased incidence of retinopathy [12], and other longitudinal studies have suggested that the inflection point for retinopathy may not be at $\mathrm{HbAlc}$ of $6.5 \%(48 \mathrm{mmol} / \mathrm{mol})$ [12-16]. For example, McCance et al. studied the development of retinopathy and nephropathy in Pima Indians and found that the threshold for retinopathy based on $\mathrm{HbAlc}$ was at the 80th percentile, which corresponded to $\mathrm{HbAlc} \geq 6.9 \%(52 \mathrm{mmol} / \mathrm{mol})$ [14]. van Leiden et al. published the incidence of retinopathy in individuals from the Hoorn study, a population-based cohort study on glucose metabolism in Netherlands [16], and showed that the participants in the highest HbAlc group (HbAlc $5.8-13.1 \%$ or $40-120 \mathrm{mmol} / \mathrm{mol}$ ) had $21.1 \%$ incidence of retinopathy, with an odds ratio of 3.95 (95\% confidence interval: 1.19, 13.03). Because the range of $\mathrm{HbAlc}$ in this group was very wide, a clear cut-off point could not be determined. Selvin et al. studied the association between HbAlc and the risk of kidney disease and retinopathy in a community-based population during a median of 14 years of follow-up [15]. The study did not find an HbAlc threshold for microvascular outcomes before or after adjusting covariates. The DESIR study examined 700 subjects for development of retinopathy at 10-year follow-up and found that the positive predictive values for retinopathy increased sharply at HbAlc of $6.0 \%$ (42 mmol/mol) [13]. Based on these longitudinal studies, $\mathrm{HbAlc} \geq 6.5 \%(48 \mathrm{mmol} / \mathrm{mol})$ has not been validated as the inflection point at which the risk of retinopathy increases in the general population [17]. Thus, the current diagnostic cutoff for diabetes based on HbAlc is still in a quandary, and it is highly likely that the diagnostic criterion based on HbAlc will be revised in the future.

The diagnostic criteria of diabetes have been evolving over time. Diabetes was previously diagnosed by fasting plasma glucose $(\mathrm{FPG}) \geq 140 \mathrm{mg} / \mathrm{dL}(7.8 \mathrm{mmol} / \mathrm{L})$ or a $2-$ hour plasma glucose (2hPG) level $\geq 200 \mathrm{mg} / \mathrm{dL}$ (11.1 mmol/L), based on the criteria established by the National Diabetes Data Group in 1979 [18]. In 1997, the fasting glucose threshold was decreased to $126 \mathrm{mg} / \mathrm{dL}(7.0 \mathrm{mmol} / \mathrm{L})$ [19], which was intended to reflect the discrepancy between $2 \mathrm{hPG}$ and FPG (many subjects have a $2 \mathrm{hPG} \geq 200 \mathrm{mg} / \mathrm{dL}$ or $11.1 \mathrm{mmol} / \mathrm{L}$ and a FPG $<140 \mathrm{mg} / \mathrm{dL}$ or $7.8 \mathrm{mmol} / \mathrm{L}$ ) and to simplify the diagnostic process (fasting blood test versus oral glucose tolerance test, OGTT). In 2009, HbAlc was defined as one of the diagnostic criteria for diabetes [10].

The National Health and Nutrition Examination Survey (NHANES) is a program designed to assess the health and nutritional status of adults and children in the United States. It has been conducting continuous surveys in different population groups across the country and surveys a variety of demographic, socioeconomic, dietary, and health groups. Based on the datasets from NHANES 2005-2010, we examined the effectiveness of using HbAlc in diagnosing diabetes compared to FPG and $2 \mathrm{hPG}$ in a previously undiagnosed diabetic cohort. As this was a cross-sectional study, we could not examine the impact of diagnostic criteria on the longterm diabetic complications. Instead, we investigated the agreement of the current diagnostic criteria for diabetes to facilitate the early diagnosis of diabetes in the present study.

\section{Methods}

2.1. Ethics Statement. The NHANES has been conducted by the National Center for Health Statistics of the Centers for Disease Control and Prevention in the United States since the 1960s. The purpose of this survey is to assess the health and nutrition status of a large representative sample in the United States and to provide vital and health statistics for the nation. The survey and data collection were approved by the NHANES Institutional Review Board (IRB) and documented consent was obtained from participants. Only deidentified data from the survey was used in this study, and its use is exempt from the federal regulations for the protection of human research participants as previously described [20].

2.2. Study Design and Study Sample. Detailed descriptions of the survey and the analytical methods of various assays have been updated regularly and are available at its website (http://www.cdc.gov/nchs/about/major/nhanes/datalink.htm \#NHANESIII) and described previously [21].

2.3. Study Population. NHANES is a population-based survey designed to be representative of the US civilian noninstitutionalized population. Starting in 2007, NHANES began oversampling all Hispanics. Previous survey periods (19992002 and 2003-06) oversampled Mexican Americans only and certain other groups (i.e., low income persons, adolescents, the elderly, and blacks). Databases from the NHANES from years 2005 through 2010 were evaluated for the study 


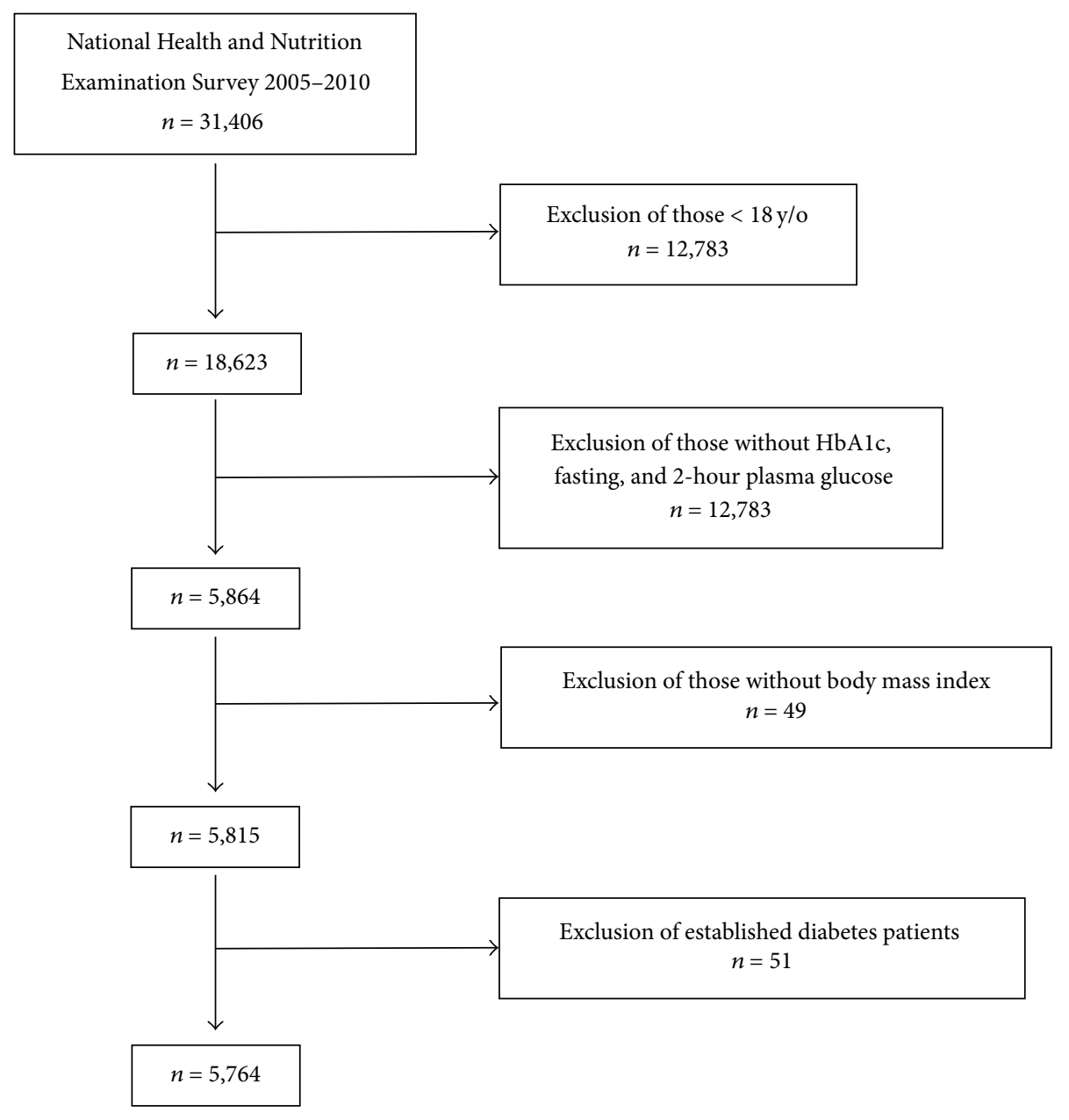

FIGURE 1: Sampling scheme.

$(n=31,406)$. There were 5,815 subjects, 18 years old or older, who had a measured HbAlc, 2hPG, FPG, and body mass index (BMI). Those who had established diabetes based on the history of self-reported diabetes or by use of insulin and/or oral antidiabetic agents were excluded $(n=51)$. The present sample set consisted of 5,764 subjects without a prior diagnosis of diabetes (Figure 1).

2.4. Diagnostic Criteria of Diabetes. For this study, in accordance with the guidelines set forth by the American Diabetes Association, diabetes was defined as having a FPG $\geq$ $126 \mathrm{mg} / \mathrm{dL}$ (7.0 mmol/L), $2 \mathrm{hPG} \geq 200 \mathrm{mg} / \mathrm{dL}$ (11.1 mmol/L), or $\mathrm{HbAlc} \geq 6.5 \%(48 \mathrm{mmol} / \mathrm{mol})[22]$.

\subsection{Laboratory Methods}

2.5.1. HbA1c. HbAlc was measured using HPLC based assays. HbAlc measurements were determined using a Tosoh Alc 2.2 Plus Glycohemoglobin Analyzer during NHANES 20052006 and a Tosoh Alc G7 HPLC Glycohemoglobin Analyzer during NHANES 2007-2008 and 2009-2010. Although different HbAlc laboratory instruments and laboratories were used between 2005 and 2010, laboratory method crossover studies were conducted at the time of the laboratory instrument changes. Both laboratories analyzing NHANES HbA1c data from 1999 to 2010 were standardized by participating in the NGSP. A laboratory group from the NGSP system was consulted in February 2012 to review the NHANES laboratory and participant hemoglobin HbAlc data. The NGSP group concluded that both NHANES laboratories met NGSP criteria for bias and precision from 1999 to 2010. Thus, no crossover regression was made in the present study. The rereleased hemoglobin A1c data for 2007-2008 (GHB_E) and 2009-2010 (GHB_F) in March 2012 was used in this study.

2.5.2. Plasma Glucose Concentration. Plasma glucose concentration was determined by a hexokinase method which is an endpoint enzymatic method using a sample blank correction. As OGTT was not performed between 1999 and 2004, we only included the 2005-2010 data in this analysis. Beginning in 2005, an OGTT was reintroduced to the laboratory protocol for NHANES. A fasting blood test was performed on all participants 12 years old and older; these participants were examined in the morning session, following a 9-hour fast. After the initial venipuncture, participants were asked to drink a calibrated dose (75 grams of glucose), and a 
TABLE 1: Clinical features of studied subjects.

\begin{tabular}{lccc}
\hline & Mean $(n)$ & & STD $^{*}(\%)$ \\
\hline$n$ & 5,764 & & \\
Age, year & 46 & \pm & 19 \\
Gender, female & 2,873 & & $49.8 \%$ \\
Body mass index, kg/m ${ }^{2}$ & 28.4 & \pm & 6.5 \\
Systolic blood pressure, mmHg & 121 & \pm & 17 \\
Diastolic blood pressure, mmHg & 68 & \pm & 12 \\
\hline Current smoking, yes & 1,479 & & $25.7 \%$ \\
Alcohol consumption, yes & 3,801 & & $65.9 \%$ \\
Family history of diabetes, yes & 1,983 & & $34.4 \%$ \\
\hline HbAlc, \% & 5.5 & \pm & 0.6 \\
HbAlc, mmol/mol & 36 & \pm & 6 \\
Fasting plasma glucose, mg/dL & 101 & \pm & 18 \\
Fasting plasma glucose, mmol/L & 6.1 & \pm & 1.0 \\
Two-hour plasma glucose, mg/dL & 119 & \pm & 52 \\
Two-hour plasma glucose, mmol/L & 6.6 & \pm & 2.9 \\
\hline Racial/ethnic group & & & \\
$\quad$ Mexican Americans & 1,117 & & $19.4 \%$ \\
Other Hispanics & 519 & & $9.0 \%$ \\
Non-Hispanic Whites & 2,812 & & $48.9 \%$ \\
Non-Hispanic Blacks & 1,060 & & $18.4 \%$ \\
Others & 250 & & $4.3 \%$ \\
\hline
\end{tabular}

*STD: standard deviation.

second venipuncture was performed 2 hours ( \pm 15 minutes) later.

2.6. Statistical Analysis. Continuous data were expressed as mean \pm standard deviation (STD), unless otherwise specified. Continuous differences were examined using a twotail Student's $t$-test. Categorical differences were given in proportions and examined using a Chi-square test. $P<0.05$ was considered statistically significant. Regression analysis was used to examine the relation of HbAlc with FPG and 2hPG. Cohen's kappa coefficient was calculated to assess the agreement between $\mathrm{HbAlc}$ and FPG and between HbAlc and $2 \mathrm{hPG}$. The fitted receiver operating characteristic (ROC) curve was calculated using a web-based calculator, and the fitted ROC curve was plotted with 95\% confidence interval (Eng J. ROC analysis: web-based calculator for ROC curves. Baltimore: Johns Hopkins University (updated September 11, 2007), available from http://www.jrocfit.org/. Access on October 20, 2013).

\section{Results}

3.1. Studied Population. The clinical characteristics of 5,764 subjects in this study are shown in Table 1 . The study consisted of 1,117 Mexican Americans (19.4\%), 519 other Hispanics (9.0\%), 2,818 non-Hispanic Whites (48.9\%), 1,060 non-Hispanic Blacks (18.4\%), and 250 subjects of other racial/ethnic groups $(4.3 \%)$. The cohort had a mean age of 46 years and a mean BMI of $28.4 \mathrm{~kg} / \mathrm{m}^{2}$. Based on the established diagnostic criteria, 245 (4.3\%) subjects were diabetic with FPG $\geq 126 \mathrm{mg} / \mathrm{dL}(7.0 \mathrm{mmol} / \mathrm{L}), 392$ subjects (6.8\%) were diabetic with $2 \mathrm{hPG} \geq 11.1 \mathrm{mmol} / \mathrm{L}(200 \mathrm{mg} / \mathrm{dL})$, and $146(2.5 \%)$ subjects were diabetic with $\mathrm{HbAlc} \geq 6.5 \%$ (48 $\mathrm{mmol} / \mathrm{mol})$.

3.2. Diabetes Based on Fasting Plasma Glucose versus HbAlc. Among 245 individuals that had FPG $\geq 126 \mathrm{mg} / \mathrm{dL}$ (7.0 mmol/L), 106 subjects (43.3\%) had HbAlc $\geq 6.5 \%$ ( $48 \mathrm{mmol} / \mathrm{mol})$, and 139 subjects $(56.7 \%)$ had $\mathrm{HbAlc}<6.5 \%$ (48 mmol $/ \mathrm{mol}$ ) (Table 2 ). The sensitivity and specificity of HbAlc $\geq 6.5 \%$ in diagnosing diabetes mellitus based on FPG $\geq 126 \mathrm{mg} / \mathrm{dL}(7.0 \mathrm{mmol} / \mathrm{L})$ were $43.3 \%$ and $99.3 \%$, respectively. The sensitivity differed widely among ethnic groups (Mexican Americans 50.0\%, other Hispanics 37.5\%, non-Hispanic Whites 37.8\%, non-Hispanic Blacks 51.4\%, and others $80.0 \%$ ). However, the specificity was greater than $98.0 \%$ in all ethnic groups. The positive predictive value and the negative predictive value were $72.6 \%$ and $97.5 \%$, respectively.

Subjects that met the criteria for diagnosis of diabetes mellitus based on FPG $\geq 126 \mathrm{mg} / \mathrm{dL}(7.0 \mathrm{mmol} / \mathrm{L})$ were further analyzed in two groups based on HbAlc $(<6.5 \%$ versus $\geq 6.5 \%, 48 \mathrm{mmol} / \mathrm{mol}$ ) (Table 3 ). There were no statistically significant differences between the two groups in regard to age, gender, blood pressure, current smoking, alcohol consumption, and family history of diabetes, except for HbAlc, FPG, and 2hPG. BMI approached significance $(P=$ $0.08)$, because more subjects from the group HbAlc $<6.5 \%$ $(48 \mathrm{mmol} / \mathrm{mol})$ had BMI in nonobese range. Based on the difference in HbAlc, FPG, and 2hPG, the HbAlc criterion performed poorly in those with less elevated plasma glucose and less severe diabetes when compared to the FPG criterion.

3.3. Diabetes Based on 2-Hour Plasma Glucose versus HbAlc. Out of 5,764 subjects, only 392 patients $(6.8 \%)$ had a diagnosis of diabetes using the $2 \mathrm{hPG}$ criterion (Table 4 ). Of those, only $110(28.1 \%)$ had $\mathrm{HbAlc} \geq 6.5 \%(48 \mathrm{mmol} / \mathrm{mol})$. Thus, if only the HbAlc criterion was used in these cases to diagnose diabetes, about $72 \%$ of the patients would have had a missed diagnosis of diabetes. In reference to $2 \mathrm{hPG}$, sensitivity for diagnosing diabetes using HbAlc was only $28.1 \%$ with an excellent specificity of $99.3 \%$. The HbAlc criterion had a false positive rate of $0.7 \%$, while the false negative rate was up to $71.9 \%$. These results indicate that the current HbAlc criterion performed poorly as a sole indicator of the diagnosis of diabetes when compared to the current $2 \mathrm{hPG}$ criterion.

To further elucidate the likelihood that certain characteristics would predispose subjects to have HbAlc < $6.5 \%(48 \mathrm{mmol} / \mathrm{mol})$ despite having $2 \mathrm{hPG} \geq 200 \mathrm{mg} / \mathrm{dL}$ $(11.1 \mathrm{mmol} / \mathrm{L})$, we divided subjects into those with HbAlc $<$ and those with $\mathrm{HbAlc} \geq 6.5 \%(48 \mathrm{mmol} / \mathrm{mol})$ and compared the two groups (Table 5). Patients with HbAlc $<6.5 \%$ $(48 \mathrm{mmol} / \mathrm{mol})$ were more likely to be older $(64 \pm 15$ versus $60 \pm 15$ years old, $P=0.01)$, female $(53.2 \%$ versus $38.2 \%, P=$ $0.008)$, and leaner by BMI $\left(29.7 \pm 6.1\right.$ versus $33.0 \pm 6.6 \mathrm{~kg} / \mathrm{m}^{2}$, $P<0.0001)$ and less likely to be current smokers $(18.1 \%$ versus $29.1 \%, P=0.02$ ) as compared to those with $\mathrm{HbAlc} \geq 6.5 \%$ ( $48 \mathrm{mmol} / \mathrm{mol})$. Among $5 \mathrm{racial} / \mathrm{ethnic}$ groups, the current HbAlc criterion performed best in non-Hispanic blacks by 
TABLE 2: Percentage of subjects meeting diagnostic criteria for diabetes by fasting plasma glucose and hemoglobin Alc.

\begin{tabular}{|c|c|c|c|c|c|c|}
\hline & \multicolumn{5}{|c|}{ Fasting plasma glucose } & \multirow[b]{2}{*}{ Subtotal } \\
\hline & & \multicolumn{2}{|c|}{$\begin{array}{l}<126 \mathrm{mg} / \mathrm{dL} \\
(<7 \mathrm{mmol} / \mathrm{L})\end{array}$} & \multicolumn{2}{|c|}{$\begin{array}{l}\geq 126 \mathrm{mg} / \mathrm{dL} \\
(\geq 7 \mathrm{mmol} / \mathrm{L})\end{array}$} & \\
\hline \multirow{2}{*}{ HbAlc } & $<6.5 \%(<48 \mathrm{mmol} / \mathrm{mol})$ & 5,479 & $99.3 \%$ & 139 & $56.7 \%$ & 5,618 \\
\hline & $\geq 6.5 \%(<48 \mathrm{mmol} / \mathrm{mol})$ & 40 & $0.7 \%$ & 106 & $43.3 \%$ & 146 \\
\hline Subtotal & & 5,519 & & 245 & & 5,764 \\
\hline
\end{tabular}

$n$ with column percent.

TABLE 3: Comparison of clinical characteristics of subjects with fasting plasma glucose $\geq 126 \mathrm{mg} / \mathrm{dL}$ ( $\geq 7.0 \mathrm{mmol} / \mathrm{L}$ ) stratified by HbAlc $<$ or $\geq$ $6.5 \%(48 \mathrm{mmol} / \mathrm{mol})$.

\begin{tabular}{|c|c|c|c|}
\hline & \multicolumn{2}{|c|}{ Diabetes by fasting glucose } & \multirow[b]{2}{*}{$P$} \\
\hline & $\begin{array}{c}\text { HbAlc }<6.5 \% \\
(<48 \mathrm{mmol} / \mathrm{mol})\end{array}$ & $\begin{array}{c}\text { HbAlc } \geq 6.5 \% \\
(\geq 48 \mathrm{mmol} / \mathrm{mol})\end{array}$ & \\
\hline$n$ & 139 & 106 & \\
\hline Age, year & $61 \pm 15$ & $59 \pm 15$ & NS \\
\hline Gender, female & $49(35.3 \%)$ & $39(36.8 \%)$ & NS \\
\hline Body mass index, $\mathrm{kg} / \mathrm{m}^{2}$ & $31.4 \pm 7.2$ & $33.0 \pm 7.0$ & NS \\
\hline Systolic blood pressure, mmHg & $129 \pm 20$ & $132 \pm 20$ & NS \\
\hline Diastolic blood pressure, $\mathrm{mmHg}$ & $71 \pm 13$ & $71 \pm 15$ & NS \\
\hline Current smoking, yes & $33(23.7 \%)$ & $34(32.1 \%)$ & NS \\
\hline Alcohol consumption, yes & $98(70.5 \%)$ & $69(65.1 \%)$ & NS \\
\hline Family history of diabetes, yes & $61(43.9 \%)$ & $33(31.1 \%)$ & NS \\
\hline $\mathrm{HbAlc}, \%$ & $5.8 \pm 0.5$ & $8.0 \pm 1.8$ & $<0.0001$ \\
\hline $\mathrm{HbAlc}, \mathrm{mmol} / \mathrm{mol}$ & $40 \pm 3$ & $64 \pm 14$ & \\
\hline Fasting plasma glucose, mg/dL & $136 \pm 19$ & $180 \pm 58$ & $<0.0001$ \\
\hline Fasting plasma glucose, $\mathrm{mmol} / \mathrm{L}$ & $7.6 \pm 1.1$ & $10.0 \pm 3.2$ & \\
\hline Two-hour plasma glucose, mg/dL & $195 \pm 64$ & $315 \pm 90$ & $<0.0001$ \\
\hline Two-hour plasma glucose, $\mathrm{mmol} / \mathrm{L}$ & $10.8 \pm 3.6$ & $17.5 \pm 5.0$ & \\
\hline Racial/ethnic group & & & NS \\
\hline Mexican Americans & $26(18.7 \%)$ & $26(24.5 \%)$ & \\
\hline Other Hispanics & $15(10.8 \%)$ & $9(8.5 \%)$ & \\
\hline Non-Hispanic Whites & $79(56.8 \%)$ & $48(45.3 \%)$ & \\
\hline Non-Hispanic Blacks & $18(13.0 \%)$ & $19(17.9 \%)$ & \\
\hline Others & $1(0.7 \%)$ & $4(3.8 \%)$ & \\
\hline
\end{tabular}

Mean \pm standard deviation or $n$ with percent; NS, not significant.

successfully identifying $51.2 \%$ of subjects (22 out of 43 ) with $2 \mathrm{hPG} \geq 200 \mathrm{mg} / \mathrm{dL}(11.1 \mathrm{mmol} / \mathrm{L})$. In contrast, only $28.6 \%$ (26 out of 121) in Mexican Americans, 27.3\% (3 out of 11) in other racial/ethnic groups, $25.7 \%$ (9 out of 35) in other Hispanics, and 22.5\% (50 of 222) in non-Hispanic whites were successfully identified $(P=0.004)$. Based on the difference in $\mathrm{HbAlc}, \mathrm{FPG}$, and $2 \mathrm{hPG}$, the HbAlc criterion performed poorly in those with less elevated plasma glucose and less severe diabetes when compared to the $2 \mathrm{hPG}$ criterion.

When stratifying the subjects by different BMI (Figure 2(a)), there was a progressive trend of subjects to have an $\mathrm{HbAlc}<6.5 \%(48 \mathrm{mmol} / \mathrm{mol})$ as BMI decreased. In lean subjects $\left(\mathrm{BMI}<25.0 \mathrm{~kg} / \mathrm{m}^{2}\right.$ ), only $17.4 \%$ of the diabetic subjects defined by $2 \mathrm{hPG}$ had an $\mathrm{HbAlc} \geq 6.5 \%$ $(48 \mathrm{mmol} / \mathrm{mol})$. Subjects with higher BMI tended to have fewer missed diagnosis of diabetes when using the HbAlc criterion. The cohort was also stratified into different age groups (Figure 2(b)). In the elderly subjects (age $\geq 70$ years), only $19.62 \%$ of the diabetic subjects defined by $2 \mathrm{hPG}$ had $\mathrm{HbAlc} \geq 6.5 \%(48 \mathrm{mmol} / \mathrm{mol})$. Younger subjects tended to have fewer missed diagnosis of diabetes when using the HbAlc criterion except for the 40-49 age group.

3.4. Regression Analysis. Regression analysis was used to find an equivalent $\mathrm{HbAlc}$ value in respect to FPG (Figure 3 ). The FPG and HbAlc correlated very well to a linear relationship defined as HbAlc $(\%)=3.1151+0.0232 \times$ FPG $(\mathrm{mg} / \mathrm{dL})(r=$ $0.7058, P<0.000001)$. Based on this relationship, a FPG of $126 \mathrm{mg} / \mathrm{dL}(7.0 \mathrm{mmol} / \mathrm{L})$ correlated closer to an HbAlc of 
TABLE 4: Distribution of diabetic states by 2-hour plasma glucose and HbAlc.

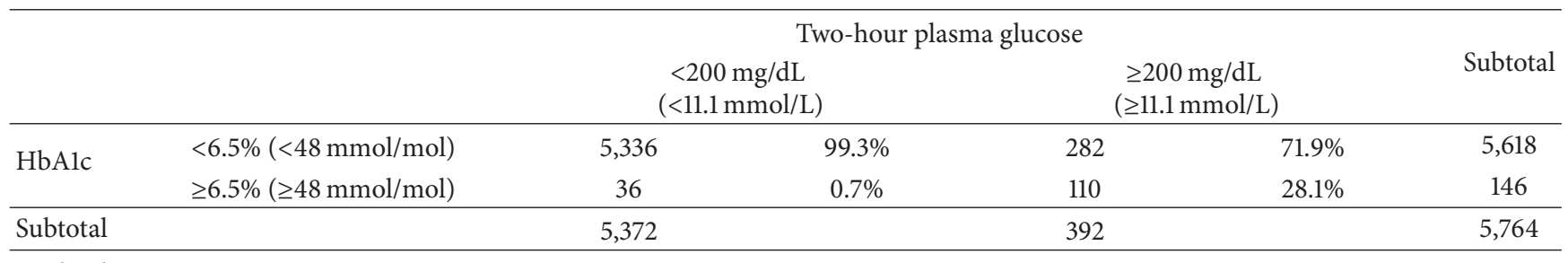

$n$ with column percent.

TABLE 5: Comparison of clinical characteristics of subjects with 2-hour plasma glucose $\geq 200 \mathrm{mg} / \mathrm{dL}$ ( $\geq 11.1 \mathrm{mmol} / \mathrm{L})$ stratified by HbAlc $<$ or $\geq 6.5 \%(48 \mathrm{mmol} / \mathrm{mol})$.

\begin{tabular}{|c|c|c|c|}
\hline & Diabe & glucose & \\
\hline & $\begin{array}{c}\text { HbAlc }<6.5 \% \\
(<48 \mathrm{mmol} / \mathrm{mol})\end{array}$ & $\begin{array}{c}\text { HbAlc } \geq 6.5 \% \\
(\geq 48 \mathrm{mmol} / \mathrm{mol})\end{array}$ & $P$ \\
\hline$n$ & 282 & 110 & \\
\hline Age, year & $64 \pm 15$ & $60 \pm 15$ & 0.01 \\
\hline Gender, female & $150(53.2 \%)$ & $42(38.2 \%)$ & 0.008 \\
\hline Body mass index, $\mathrm{kg} / \mathrm{m}^{2}$ & $29.7 \pm 6.1$ & $33.0 \pm 6.6$ & $<0.0001$ \\
\hline Systolic blood pressure, mmHg & $132 \pm 20$ & $132 \pm 20$ & NS \\
\hline Diastolic blood pressure, $\mathrm{mmHg}$ & $68 \pm 13$ & $70 \pm 14$ & NS \\
\hline Current smoking, yes & $51(18.1 \%)$ & $32(29.1 \%)$ & 0.02 \\
\hline Alcohol consumption, yes & $192(68.1 \%)$ & $74(67.3 \%)$ & NS \\
\hline Family history of diabetes, yes & $110(39.0 \%)$ & $52(47.3 \%)$ & NS \\
\hline HbAlc, \% & $5.7 \pm 0.4$ & $7.9 \pm 1.8$ & $<0.0001$ \\
\hline $\mathrm{HbAlc}, \mathrm{mmol} / \mathrm{mol}$ & $39 \pm 5$ & $63 \pm 18$ & \\
\hline Fasting plasma glucose, mg/dL & $83 \pm 20$ & $176 \pm 60$ & $<0.0001$ \\
\hline Fasting plasma glucose, mmol/L & $6.5 \pm 1.1$ & $9.8 \pm 3.3$ & \\
\hline Two-hour plasma glucose, mg/dL & $232 \pm 31$ & $318 \pm 82$ & $<0.0001$ \\
\hline Two-hour plasma glucose, $\mathrm{mmol} / \mathrm{L}$ & $12.9 \pm 1.8$ & $17.7 \pm 4.6$ & \\
\hline Racial/ethnic group & & & 0.004 \\
\hline Mexican Americans & $95(19.5 \%)$ & $26(23.6 \%)$ & \\
\hline Other Hispanics & $26(9.2 \%)$ & $9(8.2 \%)$ & \\
\hline Non-Hispanic Whites & $172(61.0 \%)$ & $50(45.5 \%)$ & \\
\hline Non-Hispanic Blacks & $21(7.5 \%)$ & $22(20.0 \%)$ & \\
\hline Others & $8(2.8 \%)$ & $3(2.7 \%)$ & \\
\hline
\end{tabular}

Mean \pm standard deviation or $n$ with percent; NS, not significant.

$6.0 \%$ ( $42 \mathrm{mmol} / \mathrm{mol})$. The ROC curve for HbAlc was calculated, as diagnosed by FPG $\geq 126 \mathrm{mg} / \mathrm{dL}(7.0 \mathrm{mmol} / \mathrm{L})$ (Figure 4). The fitted ROC area was 0.871 (estimated std. error $=0.014$ ). Cohen's kappa coefficient was 0.527 (95\% CI: 0.466, $0.588)$, consistent with fair agreement.

Because the cut-off value of HbAlc $6.5 \%$ (48 mmol $/ \mathrm{mL}$ ) performed poorly compared to the cut-off value of $2 \mathrm{hPG}$ $200 \mathrm{mg} / \mathrm{dL}(11.1 \mathrm{mmol} / \mathrm{L})$, we examined the correlation between HbAlc and 2hPG (Figure 5) and noted an excellent correlation with a correlation coefficient of $0.5959(P<$ $0.000001)$. However, the correlation was heavily weighted by the subjects with $2 \mathrm{hPG}<300 \mathrm{mg} / \mathrm{dL}$ because they accounted for more than $99 \%$ of samples. The estimated regression equation is $\mathrm{HbAlc}(\%)=4.6500+0.0067 \times 2 \mathrm{hPG}(\mathrm{mg} / \mathrm{dL})$. Using this equation, an HbAlc level of $6.0 \%(42 \mathrm{mmol} / \mathrm{mol})$ corresponds to a $2 \mathrm{hPG}$ level of $200 \mathrm{mg} / \mathrm{dL}(11.1 \mathrm{mmol} / \mathrm{L})$. To further evaluate the role of $\mathrm{HbAlc}$ in the diagnosis of diabetes in comparison to $2 \mathrm{hPG}$, the fitted ROC was constructed based on the 5,764 total cases (392 positive cases and 5,372 negative cases) obtained from this study (Figure 6), allowing for an examination of the sensitivity and specificity for the HbAlc criterion. The area under the fitted ROC curve was 0.8159 with an estimated standard error of 0.0128 . The accuracy of the HbAlc criterion returned in an adequate range of 0.8 to 0.9 [23]. The agreement between the HbAlc and 2hPG criteria was poor based on Cohen's kappa coefficient of 0.386 ( $95 \%$ CI: 0.334 to 0.439 ). 


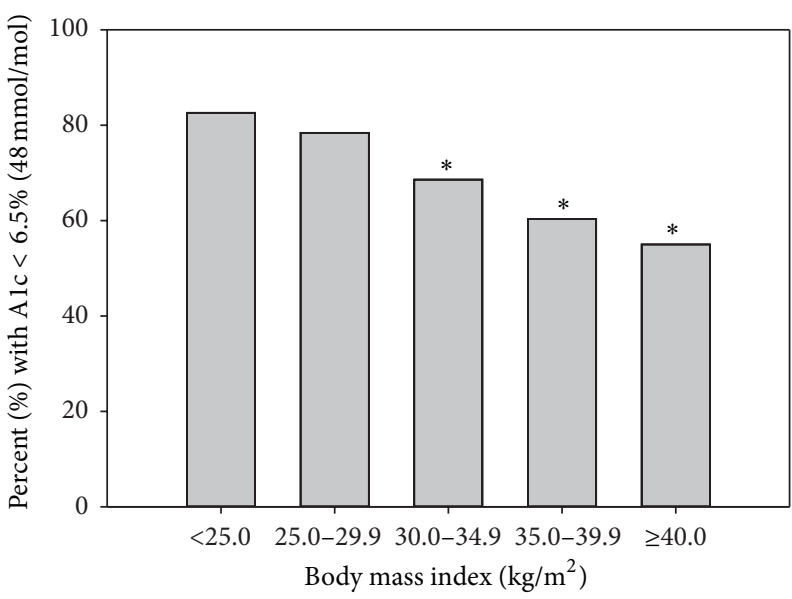

(a)

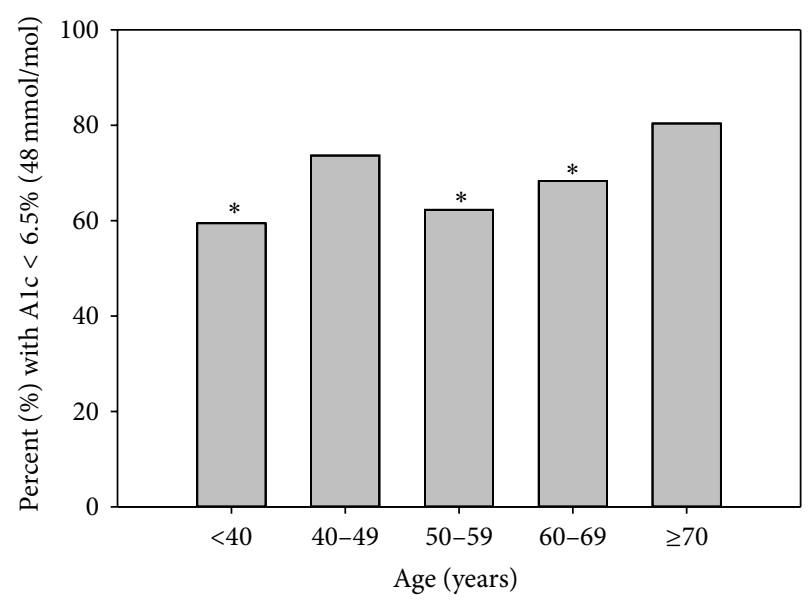

(b)

Figure 2: Percent of diabetic subjects by 2-hour plasma glucose criterion with $\mathrm{HbAlc}<6.5 \%$ ( $48 \mathrm{mmol} / \mathrm{mol}$ ) stratified by body mass index (a) and by age group (b). ${ }^{*} P<0.05$ when compared to the group with $\mathrm{BMI}<25 \mathrm{~kg} / \mathrm{m}^{2}$ in (a); ${ }^{*} P<0.05$ when compared to the group with age $\geq 70$ years in (b).

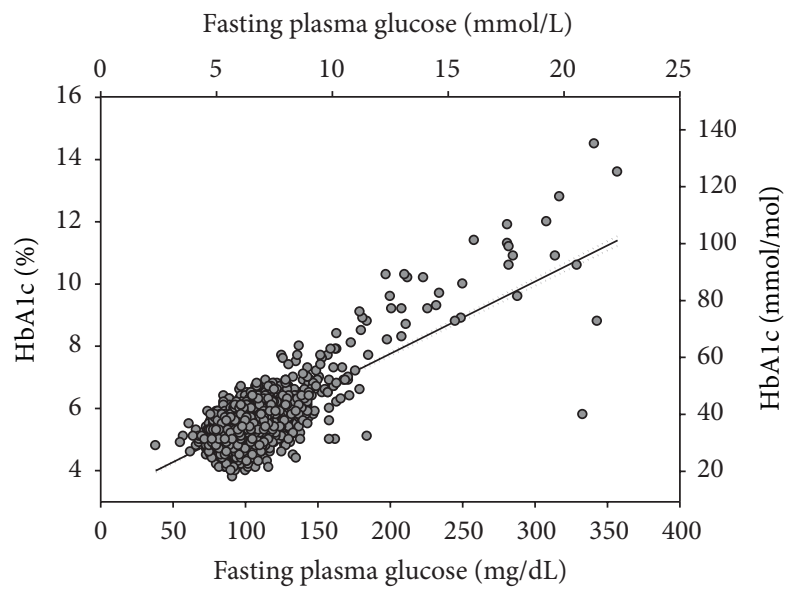

FIGURE 3: Correlation of HbAlc with fasting plasma glucose. Solid line represents the regression line. Dotted lines represent $95 \%$ confidence interval. HbAlc $(\%)=3.1151+0.0232 \times$ FPG $(\mathrm{mg} / \mathrm{dL})$.

\section{Discussion}

We conducted the present study to explore the agreement between plasma glucose (either FPG or 2hPG) and HbAlc in diagnosis of diabetes and to measure the accuracy of using $\mathrm{HbAlc} \geq 6.5 \%(48 \mathrm{mmol} / \mathrm{mol})$ as a diagnostic criterion for diabetes mellitus. We obtained our data from NHANES 2005-2010, which was designed to reflect the noninstitutionalized US population. We found that, of the 245 subjects that had FPG $\geq 126 \mathrm{mg} / \mathrm{dL}(7.0 \mathrm{mmol} / \mathrm{L})$, only 106 subjects (43.3\%) had $\mathrm{HbAlc} \geq 6.5 \%(48 \mathrm{mmol} / \mathrm{mol})$. Out of 392 subjects who had $2 \mathrm{hPG} \geq 200 \mathrm{mg} / \mathrm{dL}(11.1 \mathrm{mmol} / \mathrm{L})$, only 110 subjects $(28.1 \%)$ had $\mathrm{HbAlc} \geq 6.5 \%(48 \mathrm{mmol} / \mathrm{mol})$. The low sensitivity of the HbAlc criterion in diagnosing diabetes strongly suggests that using an $\mathrm{HbAlc} \geq 6.5 \%(48 \mathrm{mmol} / \mathrm{mol})$ as a criterion for diagnosing diabetes will likely lead to a substantial number of missed diagnoses. These results further

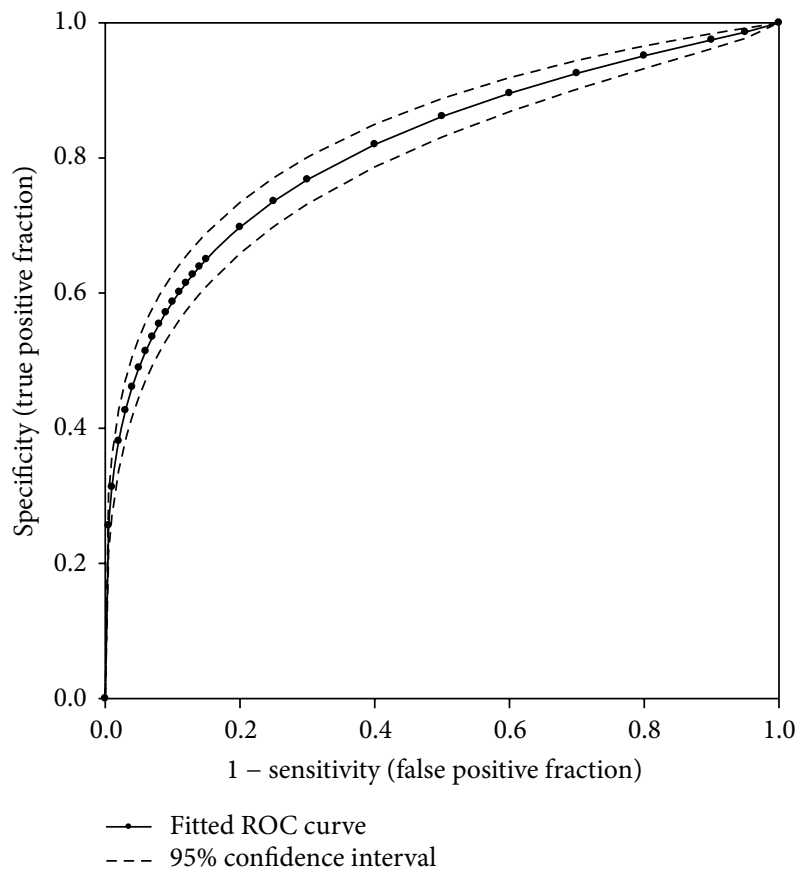

FIGURE 4: The fitted receiver operating characteristic curve of HbAlc against FPG. Solid line represents the fitted ROC. Dotted lines represent $95 \%$ confidence interval.

underscore the short comings of using the current HbAlc criterion to diagnose diabetes.

In recent years, HbAlc level has been included as a criterion for diagnosis of diabetes. Previously, HbAlc was used to monitor glycemic control in diabetic patients, because it reflects average blood glucose levels over a 2- to 3month period of time. The diagnostic threshold of HbAlc $\geq 6.5 \%(48 \mathrm{mmol} / \mathrm{mol})$ was based on the inflection point for the prevalence of retinopathy observed in extensive 


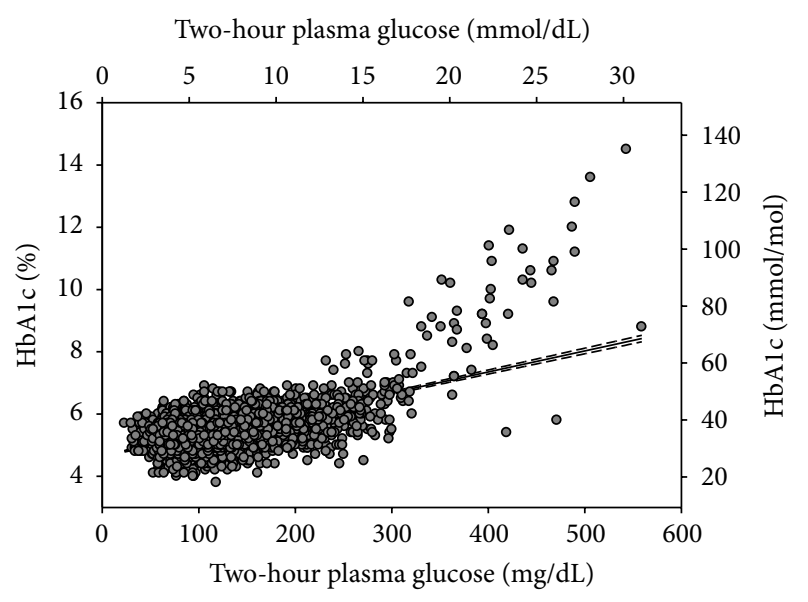

FIGURE 5: Correlation of HbAlc with 2-hour plasma glucose. Solid line represents the regression line. Dotted lines represent $95 \%$ confidence intervals of the regressive line. HbAlc $(\%)=4.6500+$ $0.0067 \times 2 \mathrm{hPG}(\mathrm{mg} / \mathrm{dL})$.

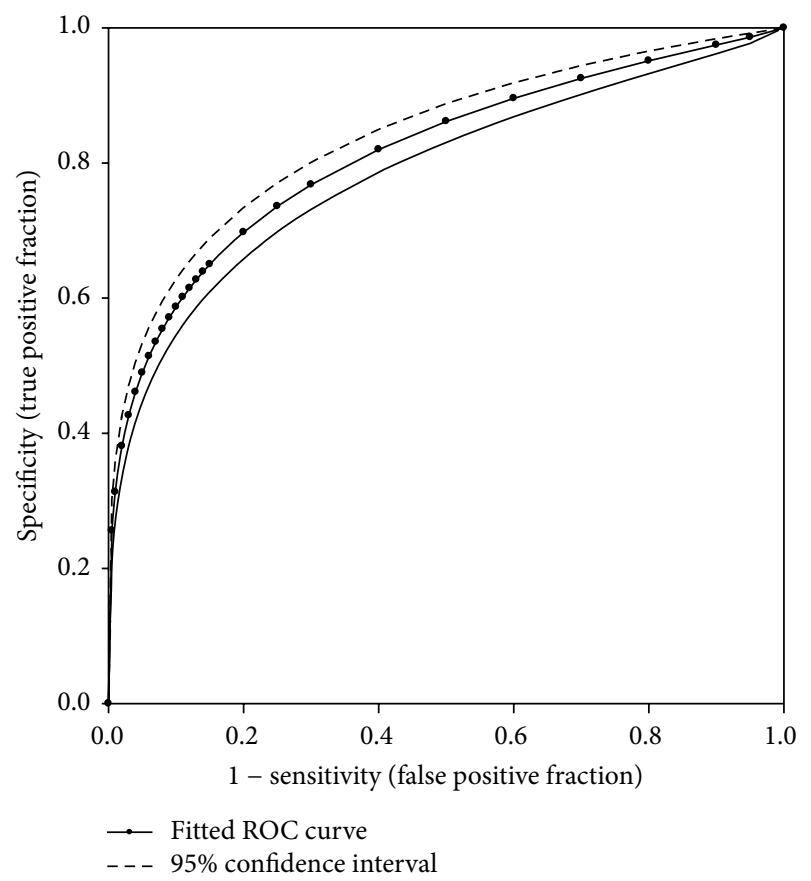

FIGURE 6: The fitted receiver operating characteristic curve of $\mathrm{HbAlc}$ against 2-hour plasma glucose.

epidemiological data [10]. However, some studies have shown that there is poor concordance between HbAlc and FPG or 2hPG during an OGTT $[24,25]$ which are the most widely accepted glucose-based methods for diagnosing diabetes. The Rancho Bernardo study, a cross-sectional study of 2,107 adults without known history of diabetes, showed that the sensitivity and specificity of $\mathrm{HbAlc} \geq 6.5 \%(48 \mathrm{mmol} / \mathrm{mol})$ against OGTT were only $44 \%$ and $79 \%$, respectively [24, 25]. Fajans et al. compared HbAlc with FPG in 147 subjects and found that one-third of subjects with early diabetes and impaired glucose tolerance (IGT) had HbAlc $<5.7 \%$ (39 mmol/mol) [24, 25].
Prior analyses of NHANES 2003-2006 data showed that the prevalence of undiagnosed diabetes using the HbAlc $\geq 6.5 \%$ ( $48 \mathrm{mmol} / \mathrm{mol}$ ) criterion was only one-third of that using the FPG $\geq 126 \mathrm{mg} / \mathrm{dL}(7.0 \mathrm{mmol} / \mathrm{L})$ criterion [26]. Using the largest samples in the reported studies to date, we confirmed the low sensitivity of HbAlc criterion in comparison to FPG criterion. Nonetheless, HbAlc remains a recommended diagnostic tool because of its practicality and convenience based on the expert opinion in cross-sectional observation studies [10]. Consequently, the actual number of individuals diagnosed with diabetes may increase due to its frequent use. Other benefits of HbAlc over FPG include stronger correlation with retinopathy [27] and less variability in dayto-day within-person variance $(<2 \%$ for $\mathrm{HbAlc}$ versus $12-$ $15 \%$ for FPG) [28].

Although using $\mathrm{HbAlC} \geq 6.5 \%(48 \mathrm{mmol} / \mathrm{mol})$ was advocated for diagnosis of diabetes, few studies have compared the sensitivity of HbAlc with 2hPG, and one study noted that 2hPG actually performed better than HbAlc in classifying diabetes [29] which was in respect to the cardiovascular complications but not retinopathy. Among Asian Americans and Native Hawaiians, the sensitivity of HbAlc $\geq 6.5 \%$ ( $48 \mathrm{mmol} / \mathrm{mol}$ ) to define diabetes was $40.0 \%$ by $2 \mathrm{hPG}$ and $68.9 \%$ by FPG only [30]. However, $64.8 \%$ of Asian subjects with diabetes had isolated postchallenge hyperglycemia, and the sensitivity of $\mathrm{HbAlc} \geq 6.5 \%(48 \mathrm{mmol} / \mathrm{mol})$ to define isolated $2 \mathrm{hPG}$ was only $19.1 \%$ [30]. In a population undergoing coronary angiography in Taiwan [31], HbAlc $\geq 6.5 \%$ $(48 \mathrm{mmol} / \mathrm{mol})$ was noted in only $39.2 \%$ of patients with $2 \mathrm{hPG} \geq 200 \mathrm{mg} / \mathrm{dL}(11.1 \mathrm{mmol} / \mathrm{L})$. Compared to these three studies, our study included the largest sample set and confirmed the low sensitivity of HbAlc criterion. Several small studies showed a low sensitivity of HbAlc in comparison with the results of OGTT [25, 32-36]. However, no information was provided in these studies specifically in reference to 2hPG. Nevertheless, their observations are consistent with our results that an $\mathrm{HbAlc} \geq 6.5 \%(48 \mathrm{mmol} / \mathrm{mol})$ has a low sensitivity in diagnosing diabetes.

Our study showed that, in reference to FPG, the current HbAlc criterion had a low sensitivity (43.3\%) and may be inadequate to detect individuals with diabetes mellitus. Consequently, we suggest that the HbAlc cut-off value should be revised for better sensitivity to better identify individuals in an early diabetic state. Correctly identifying the early diabetic state could prevent micro- and macrovascular complications or delay progression. Based on our regression analysis, the equivalent $\mathrm{HbAlc}$ value in respect to $\mathrm{FPG} 126 \mathrm{mg} / \mathrm{dL}$ $(7.0 \mathrm{mmol} / \mathrm{L})$ was closer to $6.0 \%(42 \mathrm{mmol} / \mathrm{mol})$. From our current sample set, if we use the cut-off value of $\mathrm{HbAlc} \geq$ $6.0 \%(42 \mathrm{mmol} / \mathrm{mol})$, the sensitivity and specificity are $69.8 \%$ and $91.9 \%$, respectively. Our findings are similar to those of a meta-analysis [37]. Bennett et al. reported that HbAlc of $6.1 \%$ (43 $\mathrm{mmol} / \mathrm{mol}$ ) was the recommended optimum cut-off point based on 9 studies whose reported sensitivity and specificity ranged from 78 to $81 \%$ and from 79 to $84 \%$, respectively [37]. More recent studies have shown similar findings [25, 38].

In this study, the regression analysis demonstrated good correlation between FPG and HbAlc $(r=0.7058, P<$ 0.000001). To assess the diagnostic accuracy of HbAlc, the 
fitted ROC area was calculated to be 0.871 (estimated std. error $=0.014)$ which is in agreement with another study that compared HbAlc, FPG, and 2hPG in adult Italian Caucasians [39]. Our findings demonstrated that HbAlc is a relatively good diagnostic test when compared with FPG. Nonetheless, we suggest that the cut-off value of HbAlc for diagnosing diabetes should be lowered to HbAlc $\geq 6.0 \%(42 \mathrm{mmol} / \mathrm{mol})$ which is more equivalent to $\mathrm{FPG} \geq 126 \mathrm{mg} / \mathrm{dL}(7.0 \mathrm{mmol} / \mathrm{L})$.

One of the advantages of using an HbAlc test is that it measures average blood glucose over a 3-month period. $\mathrm{HbAlc}$ also does not require patients to fast unlike FPG and is performed via a simple venipuncture unlike $2 \mathrm{hPG}$, which entails the patient to ingest 75 grams of oral glucose between blood draws. Because patients' fasting status does not need to be verified and the cumbersome procedure of coordinating the ingestion of oral glucose and laboratory draws are not necessary, testing for HbAlc provides convenience for patients and simplifies diabetes screening for health providers. However, limitations of HbAlc in reflecting chronic hyperglycemia have been reported [40]. In patients with high red blood cell turnover, HbAlc may be falsely lowered because the shortened life spans of red blood cells may lower the percentage of glycated hemoglobin regardless of the level of hyperglycemia in the blood. Patients with hemoglobinopathy will also have unreliable HbAlc. Differing levels of glycation, which have been reported in certain ethnic/racial groups, may also contribute to the discordance between HbAlc and glucose levels in patient's serum [41].

The diagnosis of diabetes is not established or confirmed based on a single test but rather by repeated measurement of FPG, 2hPG, or HbAlc [22]. Given the low sensitivity of $\mathrm{HbAlc} \geq 6.5 \%(48 \mathrm{mmol} / \mathrm{mol})$ in diagnosing diabetes in this study, we do not recommend using this criterion as a screening tool because it tends to miss the majority of the cases when compared to FPG and 2hPG. However, $\mathrm{HbAlc}$ had lower within-person variability (within-person coefficient of variation $(\mathrm{CV}): 3.6 \%$; $95 \%$ CI: $3.2,4.0)$ as compared to $2 \mathrm{hPG}$ (CV: 16.7\%; 95\% CI: 15.0, 18.3) and FPG (CV: 5.7\%; 95\% CI: 5.3, 6.1) [42]. Thus, HbAlc could be more reproducible than $2 \mathrm{hPG}$ and FGP.

Considerable strengths of the study include the large sample size, the ethnically diverse population, and the wide range of ages in the cohort. The study cohort included 245 and 392 patients who were previously undiagnosed with diabetes using FPG criterion and $2 \mathrm{hPG}$ criterion, respectively. By analyzing a large, diverse population and limiting analysis to patients who never had a previous diagnosis of diabetes, our study is more representative of the population typically screened for diabetes in clinical practice.

A clear limitation of the study is that although it was clearly demonstrated that the current HbAlc criterion failed to detect a substantial proportion of patients that have diabetes using FPG or 2hPG levels, the current study did not allow for any assessment of the clinical significance of this failure. Further studies should focus on whether diabetes related complications, such as neuropathy and nephropathy, increase when $\mathrm{HbAlc}$ reaches $6.0 \%(42 \mathrm{mmol} / \mathrm{mol})$. Future studies should also investigate the temporal influences on the discordance between the HbAlc and FPG/2hPG criteria.
TABLE 6: Performance of HbAlc on the diagnosis of diabetes in reference to fasting and 2-hour plasma glucose.

\begin{tabular}{lcc}
\hline & $\begin{array}{c}\text { Fasting plasma } \\
\text { glucose }\end{array}$ & $\begin{array}{c}\text { Two-hour plasma } \\
\text { glucose }\end{array}$ \\
\hline $\begin{array}{l}\text { Sensitivity } \\
\text { Specificity }\end{array}$ & $43.3 \%$ & $28.1 \%$ \\
$\begin{array}{l}\text { Positive predictive } \\
\text { value }\end{array}$ & $99.3 \%$ & $99.3 \%$ \\
$\begin{array}{l}\text { Negative predictive } \\
\text { value }\end{array}$ & $72.6 \%$ & $75.3 \%$ \\
$\begin{array}{l}\text { False positive rate } \\
\text { False negative rate }\end{array}$ & $97.5 \%$ & $95.0 \%$ \\
$\begin{array}{l}\text { ROC area under } \\
\text { curve (95\% CI) }\end{array}$ & $0.871(0.842,0.899)$ & $0.816(0.791,0.841)$ \\
$\begin{array}{l}\text { Cohen's kappa } \\
\text { coefficient }(95 \% \mathrm{CI})\end{array}$ & $0.527(0.467,0.588)$ & $0.386(0.334,0.439)$ \\
\hline
\end{tabular}

Studying this discordance is especially clinically relevant because patients with missed diagnosis using HbAlc may eventually be diagnosed with diabetes in the next few months or years using the same $\mathrm{HbAlC}$ criterion. Whether this delay in diagnosis will have deleterious effect on the health of an individual should also be investigated.

As summarized in Table 6, to accurately define the prevalence of diabetes and to avoid underdiagnosis of diabetes, HbAlc should be used cautiously and as a supplement to FPG and 2hPG. Our data demonstrate (Tables 3 and 5) that the HbAlc criterion is much less sensitive than FPG and $2 \mathrm{hPG}$ in diagnosing diabetes in those with mild disease. To be in agreement with FPG and 2hPG, HbAlc of $6.0 \%$ $(42 \mathrm{mmol} / \mathrm{mol}$ ) could be used as the cut-off value to prevent delaying diagnosis, surveillance, and ultimately treatment of diabetes in patients. However, before recommendations of using this cut-off value, a longitudinal study is required to demonstrate whether it truly affects the long-term diabetic complications. Regardless, our results support that when the diagnosis of diabetes by HbAlc is in doubt, FPG and/or 2hPG should be used for early diagnosis of diabetes.

\section{Abbreviations}

$\begin{array}{ll}\text { 2hPG: } & \text { Two-hour plasma glucose } \\ \text { BMI: } & \text { Body mass index } \\ \text { DM: } & \text { Diabetes mellitus } \\ \text { FPG: } & \text { Fasting plasma glucose } \\ \text { NHANES: } & \text { National Health and Nutrition } \\ & \text { Examination Survey } \\ \text { OGTT: } & \text { Oral glucose tolerance test } \\ \text { ROC: } & \text { Receiver operating characteristic curve. }\end{array}$

\section{Ethical Approval}

Institutional review board statement: The National Center for Health Statistics of the Centers for Disease Control and Prevention conducted the National Health and Nutrition Examination Survey in the United States since 1960s. This survey was designed to assess the health and nutrition status of a 
large representative sample in the United States. The survey and data collection were approved by the National Health and Nutrition Examination Survey Institutional Review Board (IRB). Documented consent was obtained from participants of the National Health and Nutrition Examination Survey at the participation of survey. Only deidentified data from the survey was used in this study, and its use is exempt from the federal regulations for the protection of human research participants.

\section{Competing Interests}

The authors identify that there is no conflict of interests.

\section{Authors' Contributions}

Ken C. Chiu, Lee-Ming Chuang, and Raynald Samoa conceived and designed the study. Rudruidee Karnchanasorn, Jean Huang, and Horng-Yih Ou obtained data under the direction of Ken C. Chiu, Lee-Ming Chuang, and Raynald Samoa. Ken C. Chiu, Raynald Samoa, and Wei Feng reviewed data. Rudruidee Karnchanasorn, Jean Huang, Wei Feng, Ken C. Chiu, Lee-Ming Chuang, and Raynald Samoa did statistical analyses and interpreted data. Rudruidee Karnchanasorn, Jean Huang, Raynald Samoa, and Ken C. Chiu drafted the paper. All authors revised the paper for important intellectual content. Ken C. Chiu, Raynald Samoa, and Wei Feng provided administrative, technical, and material support. Ken C. Chiu and Raynald Samoa contributed equally as senior authors of this study.

\section{Acknowledgments}

The authors acknowledged the unrestricted research grant from the Jie Chan Chen foundation to Horng-Yih Ou, M.D., Ph.D. The authors are in debt to the graduated fellows who participated in the preparation phase of this work. They also thank Claire Park, M.D., and Jinsun Choi, M.D., for their discussions, Chris Gandhi, Ph.D., for critical reading and editing of the paper, Henry Lin for excellent support of paper preparation, and Karen Ramos for excellent logistic and administrative support of this research endeavor. The data were presented as an oral presentation (OR17-5, Abstract no. 415272) by Jinsun Choi, M.D., and a featured poster presentation (FP18-1, Abstract no. 4148) by Claire Park, M.D., at 2013 Endocrine Society's 95th Annual Meeting and Expo, San Francisco, California, on June 16, 2013 (Endocrine Review 2013; 34: OR17-5 and 2013 34: FP18-1).

\section{References}

[1] K. G. M. M. Alberti and P. Zimmet, "Epidemiology: global burden of disease-where does diabetes mellitus fit in?" Nature Reviews Endocrinology, vol. 9, no. 5, pp. 258-260, 2013.

[2] American Diabetes Association, "Economic costs of diabetes in the U.S. in 2012," Diabetes Care, vol. 36, no. 4, pp. 1033-1046, 2013.

[3] UKPDS, "Intensive blood-glucose control with sulphonylureas or insulin compared with conventional treatment and risk of complications in patients with type 2 diabetes (UKPDS 33). UK
Prospective Diabetes Study (UKPDS) Group," The Lancet, vol. 352, no. 9131, pp. 837-853, 1998.

[4] National Diabetes Statistics Report, 2014. 6-22-0014, http:// www.cdc.gov/diabetes/pubs/statsreport14/national-diabetesreport-web.pdf.

[5] W. H. Herman, W. Ye, S. J. Griffin et al., "Early detection and treatment of type 2 diabetes reduce cardiovascular morbidity and mortality: a simulation of the results of the Anglo-DanishDutch Study of Intensive Treatment in People with ScreenDetected Diabetes in Primary Care (ADDITION-Europe)," Diabetes Care, vol. 38, no. 8, pp. 1449-1455, 2015.

[6] R. M. Bookchin and P. M. Gallop, "Structure of hemoglobin $A_{\text {Ic }}$ : nature of the N-terminal $\beta$ chain blocking group," Biochemical and Biophysical Research Communications, vol. 32, no. 1, pp. 8693, 1968.

[7] S. Rahbar, O. Blumenfeld, and H. M. Ranney, "Studies of an unusual hemoglobin in patients with diabetes mellitus," Biochemical and Biophysical Research Communications, vol. 36, no. 5, pp. 838-843, 1969.

[8] R. J. Koenig, C. M. Peterson, R. L. Jones, C. Saudek, M. Lehrman, and A. Cerami, "Correlation of glucose regulation and hemoglobin $\mathrm{A}_{\mathrm{Ic}}$ in diabetes mellitus," The New England Journal of Medicine, vol. 295, no. 8, pp. 417-420, 1976.

[9] DCCT, "Erratum: Lifetime benefits and costs of intensive therapy as practiced in the diabetes control and complications trial," The Journal of the American Medical Association, vol. 278, no. 1, p. 25, 1997, The Journal of the American Medical Association, vol. 276, no. 17, pp. 1409-1415, 1996.

[10] The International Expert Committee, "International Expert Committee report on the role of the AlC assay in the diagnosis of diabetes," Diabetes Care, vol. 32, no. 7, pp. 1327-1334, 2009.

[11] R. R. Little, "Glycated hemoglobin standardization-National Glycohemoglobin Standardization Program (NGSP) Perspective," Clinical Chemistry and Laboratory Medicine, vol. 41, no. 9, pp. 1191-1198, 2003.

[12] Y. Tsugawa, O. Takahashi, J. B. Meigs et al., "New diabetes diagnostic threshold of hemoglobin A(1c) and the 3-year incidence of retinopathy," Diabetes, vol. 61, pp. 3280-3284, 2012.

[13] P. Massin, C. Lange, J. Tichet et al., "Hemoglobin Alcand fasting plasma glucose levels as predictors of retinopathy at 10 years: the French DESIR study," Archives of Ophthalmology, vol. 129, no. 2, pp. 188-195, 2011.

[14] D. R. McCance, R. L. Hanson, M.-A. Charles et al., "Comparison of tests for glycated haemoglobin and fasting and two hour plasma glucose concentrations as diagnostic methods for diabetes," British Medical Journal, vol. 308, no. 6940, pp. 1323-1328, 1994.

[15] E. Selvin, Y. Ning, M. W. Steffes et al., "Glycated hemoglobin and the risk of kidney disease and retinopathy in adults with and without diabetes," Diabetes, vol. 60, no. 1, pp. 298-305, 2011.

[16] H. A. van Leiden, J. M. Dekker, A. C. Moll et al., "Risk factors for incident retinopathy in a diabetic and nondiabetic population: the Hoorn study," Archives of Ophthalmology, vol. 121, no. 2, pp. 245-251, 2003.

[17] L. Sobrin, "Longitudinal validation of hemoglobin $A_{1 c}$ criteria for diabetes diagnosis: risk of retinopathy," Diabetes, vol. 61, no. 12, pp. 3074-3075, 2012.

[18] NDDG, "Classification and diagnosis of diabetes mellitus and other categories of glucose intolerance. National Diabetes Data Group," Diabetes, vol. 28, no. 12, pp. 1039-1057, 1979. 
[19] "Report of the expert committee on the diagnosis and classification of diabetes mellitus," Diabetes Care, vol. 20, no. 7, pp. 1183-1197, 1997.

[20] J. Huang, R. Karnchanasorn, H. Y. Ou et al., "Association of insulin resistance with serum ferritin and aminotransferasesiron hypothesis," World Journal of Experimental Medicine, vol. 5, pp. 232-243, 2015.

[21] L. R. Malamug, R. Karnchanasorn, R. Samoa, and K. C. Chiu, "The role of Helicobacter pylori seropositivity in insulin sensitivity, beta cell function, and abnormal glucose tolerance," Scientifica, vol. 2014, Article ID 870165, 7 pages, 2014.

[22] American Diabetes Association, "Diagnosis and classification of diabetes mellitus," Diabetes Care, vol. 37, supplement 1, pp. S81-S90, 2014.

[23] C. E. Metz, "Basic principles of ROC analysis," Seminars in Nuclear Medicine, vol. 8, no. 4, pp. 283-298, 1978.

[24] S. S. Fajans, W. H. Herman, and E. A. Oral, "Insufficient sensitivity of hemoglobin $\mathrm{A}_{\mathrm{Ic}}$ determination in diagnosis or screening of early diabetic states," Metabolism: Clinical and Experimental, vol. 60, no. 1, pp. 86-91, 2011.

[25] C. K. Kramer, M. R. G. Araneta, and E. Barrett-Connor, "A1C and diabetes diagnosis: the Rancho Bernardo Study," Diabetes Care, vol. 33, no. 1, pp. 101-103, 2010.

[26] C. C. Cowie, K. F. Rust, D. D. Byrd-Holt et al., "Prevalence of diabetes and high risk for diabetes using AlC criteria in the U.S. population in 1988-2006," Diabetes Care, vol. 33, no. 3, pp. 562$568,2010$.

[27] R. J. Tapp, G. Tikellis, T. Y. Wong, C. A. Harper, P. Z. Zimmet, and J. E. Shaw, "Longitudinal association of glucose metabolism with retinopathy: results from the Australian Diabetes Obesity and Lifestyle (AusDiab) study," Diabetes Care, vol. 31, no. 7, pp. 1349-1354, 2008.

[28] R. L. Ollerton, R. Playle, K. Ahmed, F. D. Dunstan, S. D. Luzio, and D. R. Owens, "Day-to-day variability of fasting plasma glucose in newly diagnosed type 2 diabetic subjects," Diabetes Care, vol. 22, no. 3, pp. 394-398, 1999.

[29] C. A. Jackson, J. S. Yudkin, and R. D. Forrest, "A comparison of the relationships of the glucose tolerance test and the glycated haemoglobin assay with diabetic vascular disease in the community. The Islington Diabetes Survey," Diabetes Research and Clinical Practice, vol. 17, no. 2, pp. 111-123, 1992.

[30] M. R. G. Araneta, A. Grandinetti, and H. K. Chang, "A1C and diabetes diagnosis among Filipino Americans, Japanese Americans, and Native Hawaiians," Diabetes Care, vol. 33, no. 12, pp. 2626-2628, 2010.

[31] J.-S. Wang, I.-T. Lee, W.-J. Lee et al., "Performance of $\mathrm{HbA}_{\mathrm{Ic}}$ and fasting plasma glucose in screening for diabetes in patients undergoing coronary angiography," Diabetes Care, vol. 36, no. 5, pp. 1138-1140, 2013.

[32] Y. Bao, X. Ma, H. Li et al., "Glycated haemoglobin Alc for diagnosing diabetes in Chinese population: cross sectional epidemiological survey," British Medical Journal, vol. 340, article c2249, 2010.

[33] A. P. Carson, K. Reynolds, V. A. Fonseca, and P. Muntner, "Comparison of A1C and fasting glucose criteria to diagnose diabetes among U.S. adults," Diabetes Care, vol. 33, no. 1, pp. 95-97, 2010.

[34] H.-Y. Li, W.-Y. Ma, J.-N. Wei et al., "Hemoglobin Alc for the diagnosis of diabetes: to replace or to guide oral glucose tolerance tests?" Journal of Diabetes Investigation, vol. 3, no. 3, pp. 259-265, 2012.
[35] Z. X. Lu, K. Z. Walker, K. O’Dea, K. A. Sikaris, and J. E. Shaw, "A1C for screening and diagnosis of type 2 diabetes in routine clinical practice," Diabetes Care, vol. 33, no. 4, pp. 817-819, 2010.

[36] E. Van't Riet, M. Alssema, J. M. Rijkelijkhuizen, P. J. Kostense, G. Nijpels, and J. M. Dekker, "Relationship between A1C and glucose levels in the general Dutch population: the new Hoorn study," Diabetes Care, vol. 33, no. 1, pp. 61-66, 2010.

[37] C. M. Bennett, M. Guo, and S. C. Dharmage, "HbA(1c) as a screening tool for detection of Type 2 diabetes: a systematic review," Diabetic Medicine, vol. 24, pp. 333-343, 2007.

[38] H. Lee, J.-Y. Oh, Y.-A. Sung et al., "Optimal hemoglobin $A_{\text {Ic }}$ cutoff value for diagnosing type 2 diabetes mellitus in Korean adults," Diabetes Research and Clinical Practice, vol. 99, no. 2, pp. 231-236, 2013.

[39] M. A. Marini, E. Succurro, F. Arturi et al., "Comparison of A1C, fasting and 2-h post-load plasma glucose criteria to diagnose diabetes in Italian Caucasians," Nutrition, Metabolism and Cardiovascular Diseases, vol. 22, no. 7, pp. 561-566, 2012.

[40] C. D. Saudek, W. H. Herman, D. B. Sacks, R. M. Bergenstal, D. Edelman, and M. B. Davidson, "A new look at screening and diagnosing diabetes mellitus," Journal of Clinical Endocrinology and Metabolism, vol. 93, no. 7, pp. 2447-2453, 2008.

[41] Y. Tsugawa, K. J. Mukamal, R. B. Davis, W. C. Taylor, and C. C. Wee, "Should the hemoglobin $A_{1 c}$ diagnostic cutoff differ between blacks and whites?: a cross-sectional study," Annals of Internal Medicine, vol. 157, no. 3, pp. 153-159, 2012.

[42] E. Selvin, C. M. Crainiceanu, F. L. Brancati, and J. Coresh, "Short-term variability in measures of glycemia and implications for the classification of diabetes," Archives of Internal Medicine, vol. 167, no. 14, pp. 1545-1551, 2007. 


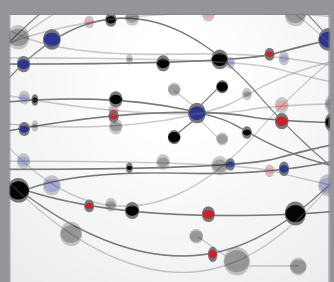

The Scientific World Journal
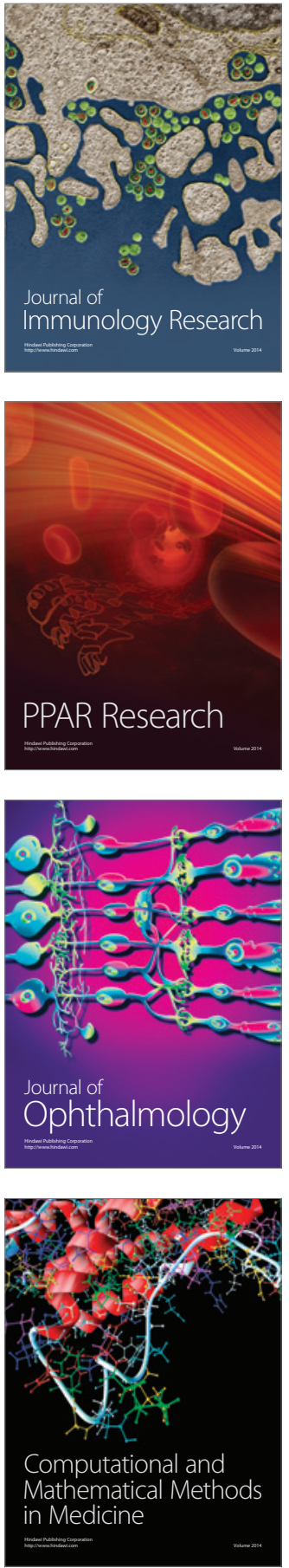

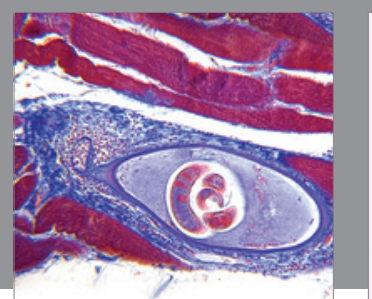

Gastroenterology Research and Practice

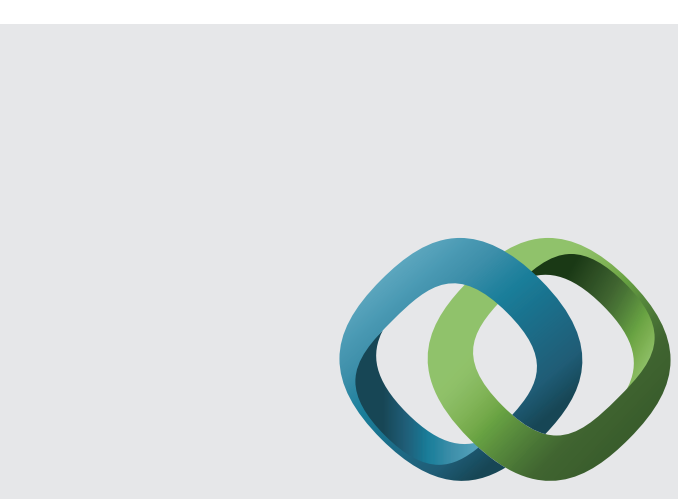

\section{Hindawi}

Submit your manuscripts at

http://www.hindawi.com
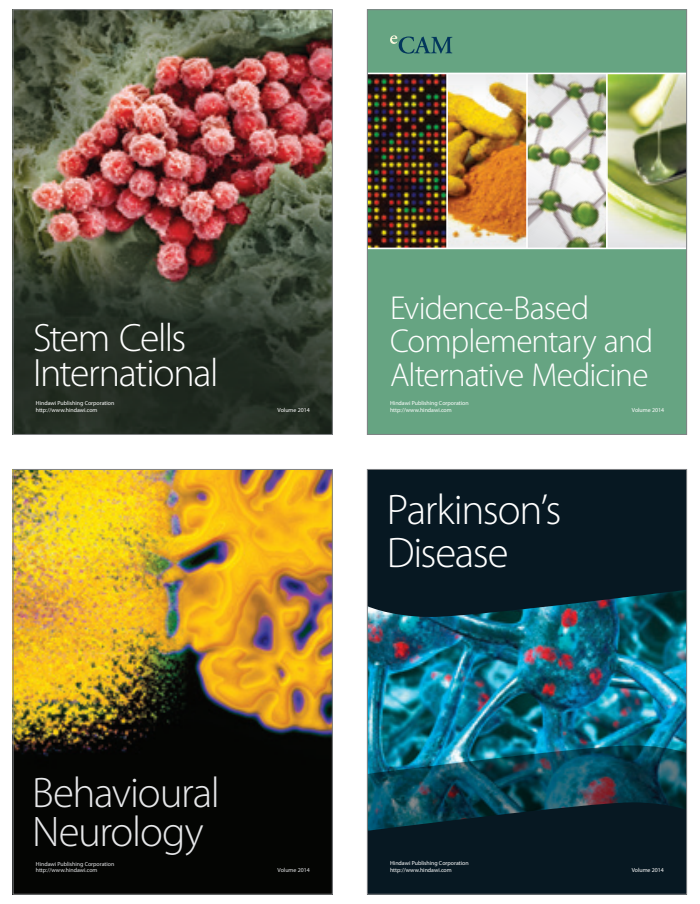
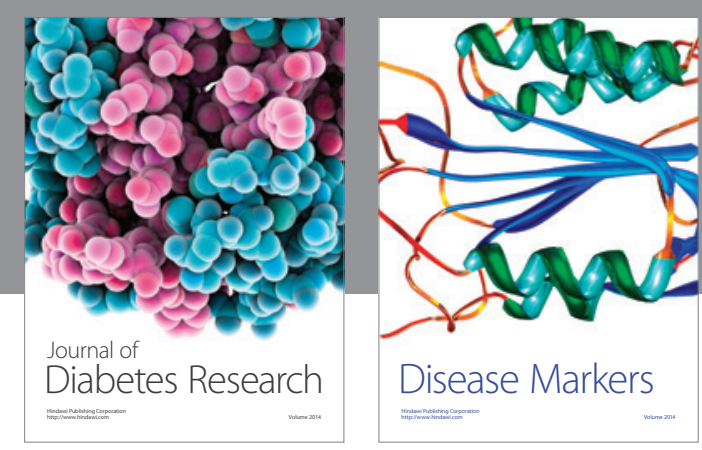

Disease Markers
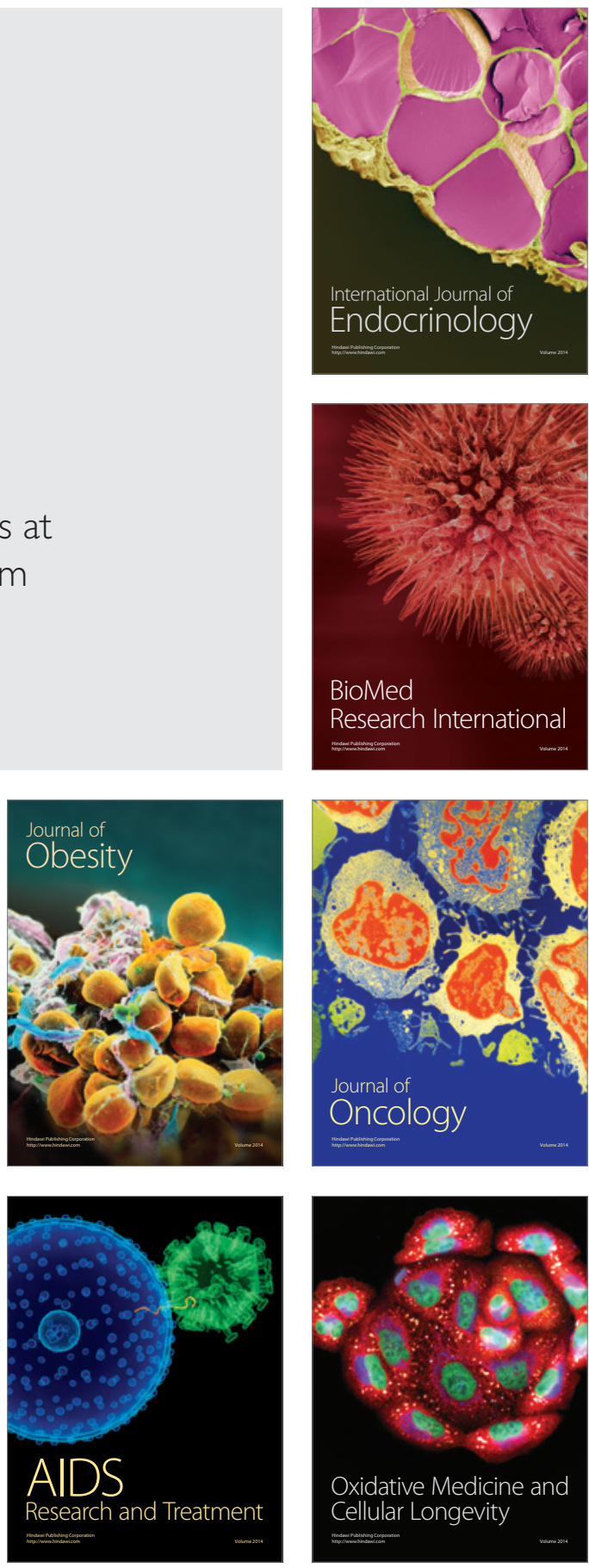